\title{
Narrative and the Reading Public in 1870s Beirut*
}

\author{
Elizabeth M. Holt \\ Bard College
}

\begin{abstract}
This paper reads narrative published in the journals of 1870 s Beirut in the context of an emerging bourgeois readership and argues that the significance of this archive to modern Arabic fiction has been neglected by critics. Taking the intensification of the silk trade with France following the civil war of 1860 as a point of historical departure, this paper traces the nexus of multiple influences upon narrative forms published in the burgeoning press of this period. Reading two serialized novels of 1870 alongside one another, this paper reveals the centrality of suspense to the proliferation of the press and the novel form. Anticipation, anxiety and hope pervade the pages of these periodicals as readers and writers negotiate changing notions of class and gender. The final portion of the paper returns to the question of influence, exposing the overdetermined narrative weave that connects these early serialized Arabic novels to not only the European novel, but also the heritage of popular Arabic storytelling epitomized by $A$ Thousand and One Nights.
\end{abstract}

\section{Keywords}

History of the press, Arabic novel, Periodicals, Beirut, The Nahdah, Serialization

Narrative published in the periodicals of 1870s and 1880s Beirut represents an archive of overwhelmingly understudied material, despite the centrality of these journals to the Nahdah. In large part this scholarly omission is due to a literary critical focus on the individual author and the bound volume, rather

* I would like to thank the many readers of this paper for their helpful comments and suggestions, and in particular wish to express my gratitude to Muhsin al-Musawi, Jason Frydman, Rashid Khalidi, and the anonymous readers of the Journal of Arabic Literature review board. The generous support of a Fulbright IIE grant, as well as multiple grants from Columbia University's Department of Middle East and Asian Languages and Cultures made possible much of the research into archives held by the American University of Beirut, Université Saint-Joseph de Beyrouth, the American University in Cairo, Columbia University, Princeton University, Harvard University and New York University. An earlier version of this paper was presented in November 2007 at the Middle East Studies Association Conference in Montreal under the title "Circulating the Arabic Serial: The Economics of Form and the Production of a Bourgeois Reading Class in 1870s Beirut," and at the Columbia Middle East and North Africa Work in Progress Workshop. The feedback that I received on these occasions was greatly appreciated. 
than a broader focus on debates surrounding the reader or the various forms of prose fiction printed in journals. Another factor is the academic trend that takes Egyptian novels written around the turn of the twentieth century as the beginning of modern Arabic narrative. This article redresses this critical gap, tracing the production of a bourgeois reading class across the pages of these journals, and revealing the engagement of narrative published in periodicals of the period with this readership's emergent narrative desires.

The aftermath of the Druze-Maronite War of $1860,{ }^{1}$ marked in part by the intensification of the raw silk trade with France and the establishment by missionaries from the United States of new educational institutions such as the Syrian Protestant College, deeply affected the social fabric of late nineteenth-century Beirut and its environs. As the booming 1860s came to an end, an unprecedented spate of new Arabic journals began to publish in Beirut in 1870 and 1871, quickly flooding what had until then been a relatively untapped periodical market. Among these new journals were al-jinān, al-Zahrah, al-Nahlah, al-Bashìr, al-Jannah, al-Najäh, al-Nashrah al-Usbü iyyah and al-Junaynah. Working with extant copies of this periodical archive, this article considers how editors and authors interacted with readers in the pages of these journals. Interpellating their readers through parenthetical addresses, the deployment of suspense, the proffering of morals and useful information, the printing of advertisements and announcements, and the inclusion of instructions for subscription, editors sought to identify and attract a growing readership to the relatively new form of the Arabic periodical. As journals printed letters, essays, trade updates and short stories penned by their growing audience, while also holding writing competitions and trivia contests, some of these readers themselves became writers, with Jurjī Zaydān perhaps the most famous among them.

In order to maintain and expand their readership in a highly competitive market, editors in 1870s and 1880s Beirut capitalized on the very form of the periodical. Editors serialized longer narratives in regular installments. Many of these longer narratives took the form of fictional novels and novellas that hinged on suspense, enticing their audiences to become regular readers of and subscribers to a given periodical. Narratively, this tactic finds parallels with the eighteenth- and nineteenth-century French and English traditions of serialized fiction, published both in periodicals as well as in number books. Its origins are overdetermined, however, for it can also be traced through the legacy

${ }^{1}$ For a detailed analysis of the events surrounding the 1860 war between Druzes and Maronites in Mount Lebanon, see: Ussama Makdisi, The Culture of Sectarianism: Community, History, and Violence in Nineteenth-Century Ottoman Lebanon (Berkeley: University of California Press, 2000). 
of popular Arabic tales such as A Thousand and One Nights and the story of 'Antar, collections that turn on the regular interruption of the narrative. Drawing upon these rich narrative sources, original prose fiction, both short and long, appeared in the pages of 1870 s and 1880s Beirut journals alongside editorials, news articles, trade updates, and essays on history, science, and morals, as well as advertisements and announcements, and the occasional poem. Subscribers received periodicals in the mail, linking them both formally and experientially with the epistolary form. Each issue of a journal would likely be shared with friends and members of the household, creating a growing network of readers, and no doubt listeners, connected not only by personal relationships but also by an expanding press that placed Beirut at the nexus of diverse local, regional, and international influences, including Arab, French, English, American and Ottoman.

The audience of these journals represented a newly emerging public. At its epicenter was a class of bourgeois readers who participated in the inauguration of Beirut as a center of education, publishing and commercial activity. The journals that appeared in 1870 and 1871, and the fiction printed in their pages, were produced by and productive of this public. Jürgen Habermas's observations regarding the relationship of the European bourgeois reading public to fiction prove pertinent to the Arabic reading public converging upon Beirut. ${ }^{2} \mathrm{He}$ writes: "the public held up a mirror to itself... through entering itself into 'literature' as an object... The public that read and debated this sort of thing read and debated about itself." 3 Indeed, the literature printed in the journals coming out of Beirut in the early 1870 s enacted a debate over the comportment proper to its newly emerging bourgeois audience. Formally, the novels, novellas and short stories of this period posed as a mirror of society by incorporating realist literary devices and addresses to the reader. Early in the decade, these tales note that they occur on precise, calendrical dates in the late 1860s and 1870. In keeping with conventions of European realism, authors routinely give only the first letter of a character's family name, or place dots in its place, as if to preserve the reputation and anonymity of their characters. These literary devices reinforce the sense that these characters are very much a part of the bourgeois public reading and debating about itself in the pages of the Beirut-based journals of 1870 and $1871 .^{4}$

\footnotetext{
2 Jens Hanssen has also noted the relevance of Habermas's work to late nineteenth-century Beirut. See: Jens Hanssen, Fin de Siècle Beirut: the Making of an Ottoman Provincial Capital (Oxford: Clarendon Press, 2005), 53.

3 Jürgen Habermas, The Structural Transformation of the Public Sphere: An Inquiry into a Category of Bourgeois Society, trans. Thomas Burger with the assistance of Frederick Lawrence (1962; Cambridge, MA: MIT Press, 1989), 38.

${ }^{4}$ By the mid-1870s, much of this specificity was replaced by a deliberate vagueness regarding
} 
One precursor to these periodicals were the proceedings of al-Jam'iyah al'ilmiyyah al-Süriyyah or the Syrian Scientific Society, which met on thirteen separate occasions between January of 1868 and May of 1869. The proceedings of each meeting were published and sent to members, some of whom lived outside of Beirut, in cities such as Alexandria and Tripoli. As Salìm Shahādah outlined in the introduction to his narrative Naqd al-'uhüd (Breaking Promises) presented at the organization's first meeting of 1869, the society placed itself at the intersection of orature and writing, calling upon its members to "compose... useful speeches to be read to those present and later printed and distributed." The society itself as well as its library were no doubt sources of inspiration to editors, journalists and readers who would go on to participate in the burgeoning periodical culture of Beirut beginning in the early 1870s. Indeed, central literary figures such as Salīm al-Bustānī and Yūsuf al-Shalfūn were active members of the society. With a reading room open to members during the day, the society's library held a collection that boasted, in addition to books in Arabic and foreign languages, issues of Arabic and French journals "for the use and enjoyment of its members," which could be checked out, one at a time, for up to fifteen days. ${ }^{6}$ Among the journals sent to the society were the Arabic newspapers Hadīqat al-Akhbār, al-Jawä̀ib, Wādì al$N \bar{i}$, and al-Mubashshir al-Tünisi, and the French-language publications L'Indépendance Belge, La Revue des deux mondes, and L'Illustration.

Khalīl al-Khūrīs seminal weekly Hadīqat al-Akhbār, founded in 1856 in Beirut, and Ahmad Fāris al-Shidyāq's newspaper al-Jawä $i b$, founded in 1861 in Istanbul but distributed widely, ${ }^{8}$ listed foreign and local news and traderelated announcements, with Hadìqat al-Akhbār also serializing fiction in

the location and date of narrative events, a vagueness to which authors such as Salīm al-Bustāni repeatedly draw the reader's attention. While there is some debate on this point, this shift suggests a growing need for negotiations with the censor, who from 1876-1880 was Khalī al-Khürī, founder of Hadiquat al-Akbbär. For more on censorship in this period, see Donald J. Cioeta, "Ottoman Censorship in Lebanon and Syria, 1876-1908," International Journal of Middle East Studies, Vol. 10, No. 2 (May, 1979), 167-186. See also Fìlīp dī Țarrāzi, Tãrìkh al-șihäafah al-'Arabiyyah (Beirut: al-Mațba'ah al-adabiyyah, 1913), especially vol. 2, 3-68; and Ami Ayalon, The Press in the Arab Middle East: A History (New York: Oxford University Press, 1995), 31-38.

${ }^{5}$ Yūsuf Qizmā Khūrī, ed., A'māl al-jam iyah al-'ilmiyyah al-Sūriyyah (Beirut: Dār al-Hamrā', 1990), 147. All translations from Arabic texts are my own unless otherwise noted.

${ }^{6}$ Ibid., 191; 2.

7 Ibid., 191.

${ }^{8}$ For more on the history of the Arabic press in late nineteenth-century Beirut, see: Fĩlip dì Țarrāzi, Tärìkh al-sihafah al-'Arabiyyah, especially vol. 2, 3-68; Ami Ayalon, The Press in the Arab Middle East: A History (New York: Oxford University Press, 1995), 31-38; Ami Ayalon, "Private Publishing in the Nahdah," International Journal of Middle East Studies Vol. 40 (2008): 561-77; Jurjī Zaydān, Tarìkh adāb al-lughah al-Arabiyyah vol. 4 (Cairo: Dār al-Hilāl, 1957), written in 1914, especially 56; 208-17; and 242-46. 
translation, such as an Arabic rendering of Fénelon's influential novel Mawqi al-aflàk fìwaqa ${ }^{\prime} i$ tilìmäk (translated from the French original Les Aventures de Télémaque) during much of the 1860s. In his 1859 lecture "Khuṭbah fī ādāb al-Arab" (A Lecture on the culture of the Arabs), ${ }^{9}$ Buțrus al-Bustānī draws his audience's attention to the founding of Hadiqat al-Akhbār, noting that its printing press al-Matba'ah al-Süriyyah was "the first Arabic press specializing in journals," which he hopes "will become stronger" with time. ${ }^{10}$ Al-Bustānīs aspirations for the future of the periodical press in Beirut are in keeping with his conviction, articulated in his seminal "Khuṭbah fī ādāb al-'Arab," that "there is no doubt that journals [jurnālät] are among the greatest means to civilize people and to increase the number of readers if they are used properly." 11 This sentiment is shared by the American Protestant weekly al-Nashrah al-Usbüiyyah, revealing perhaps the interaction that al-Bustāni had with the mission as one of its converts. The publication notes in 1871 , its first year, that journals are "among the greatest means of success" and contribute to "the spread of civilization and knowledge." This declaration is followed by a chart listing the ratio of citizens per journal in a number of countries, with the Ottoman Empire coming in second to last after Russia. America, France and England were held out as examples of salutary citizen-to-journal ratios, ${ }^{12}$ in keeping with those countries' influence upon prominent members of the Beirut bourgeoisie such as al-Bustānī, his son, and others.

Indeed, in the wake of the civil war of 1860, Beirut witnessed the founding of a number of institutions of learning and scholarship that would increase the number of possible periodical readers as well as writers in the next decade. New schools opened their doors, including al-Madrasah al-wataniyyah or the National School founded by Buțrus al-Bustānī in 1863 and the Syrian Protestant College (later to become the American University of Beirut) founded by American Presbyterian missionaries in 1866, while an 1869 Ottoman law called for the construction of an imperial Lycée, which would be known as al-Madrasah al-sultanniyyah or the Sultanate School. ${ }^{13}$ The aforementioned

9 Credit is due to Stephen Sheehi for bringing the importance of this khutbah to the attention of contemporary scholars in his recent study Foundations of Modern Arab Identity (Miami: University Press of Florida, 2004).

${ }^{10}$ Buțrus al-Bustānī, "Khuṭbah fī Ādāb al-'Arab," in al-Jam 'iyah al-Sūriyyah li-l-ulūm wa-l-funūn 1847-1852, ed. Yūsuf Qizmā Khūrī (Beirut: Dār al-Hamrāo’, 1990), 115. Lecture originally published in Beirut by al-Maṭba'ah al-Amīrkāniyyah in 1859. Lecture given on February 15, 1859.

11 Ibid.

12 Al-Nashrah al-Usbüiyyah 1:29 (1871), 2-3.

13 On educational and scholarly institutions during this period, see: Jens Hanssen, "Chapter IV: The Birth of an Educational Quarter: Zokak el-Blat as a Cradle of Cultural Revival in the Arab World," in History, Space and Social Conflict in Beirut: The Quarter of Zokak el-Blat, eds. Hans Gebhardt, Dorothée Sack, Ralph Bodenstein, Andreas Fritz, Jens Hanssen, Bernhard Hillenkamp, 
Syrian Scientific Society was founded in 1868 and was partly modeled on the earlier al-Jam'iyyah al-Süriyyah li-l-ulüm wa-l-funün or Syrian Society for the Sciences and Arts, which met from 1848 through 1852, which itself was modeled on an earlier society known as Majma al-tahdhīb, which loosely translates as the Assembly of Culture or Refinement, founded in $1847 .{ }^{14}$ These learned societies participated in the creation of an educated bourgeoisie, but by 1869 they had fallen short of accommodating this class's emerging needs. As Salīm Farij, a member of the Syrian Scientific Society noted at what would be the group's final meeting:

We see that a large number of societies... have fallen. For it is easy for all of us to meet at the beginning of the matter, but we find it less easy to keep the obligations of these meetings... I hope that this society's path will not be like those earlier ones that have fallen. ${ }^{15}$

Though new learned societies and salons would emerge, the Syrian Scientific Society, like its predecessors, dissolved, in part due to the shared sentiment that it was becoming increasingly difficult to continue to regularly meet in person. Several months later witnessed the beginning of the 1870 boom in new journals, with former members of these learned societies playing central roles in the new periodical industry as editors, writers and readers.

The center of cultural gravity shifted in Beirut in the late 1860s and early 1870 s from the learned society, in which members belonged to a community of writers, readers and orators with whom they met in person, to that of the periodical, a form that relied on print and mechanical reproduction to generate a readerly sense of simultaneous experience. In Imagined Communities, Benedict Anderson observes:

The newspaper is merely an 'extreme form' of the book, a book sold on a colossal scale, but of ephemeral popularity. Might we say: one-day best-sellers. The obsolescence of the newspaper on the morrow of its printing... for just this reason, creates this extraordinary mass ceremony: the almost precisely simultaneous consumption ('imagining') of the newspaper-as-fiction... The significance of this mass ceremony ... is paradoxical. It is performed in silent privacy, in the lair of the skull. Yet each communicant is well aware that the ceremony he performs is being replicated simultaneously by thousands. ${ }^{16}$

Oliver Kögler, Anne Mollenhauer, and Friederike Stolleis (Beirut: Orient Institute, 2005): 14374; and Tarrāzi, Târikkh al-sihafah al-'Arabiyyah, vol. 2: 1-8.

${ }^{14}$ See al-Jam'iyah al-Süriyyah li-l-'ulüm wa-l-funūn, Khūri, ed., 5-6.

${ }^{15}$ A'mäl al-jam'iyah al-ilmiyyah al-Süriyyah, Khūri, ed., 192.

${ }^{16}$ Benedict Anderson, Imagined Communities (New York: Verso, 1983), 34-5. 
The market for periodicals published in Beirut in 1870 had not reached the thousands conjured up in Anderson's depiction of the newspaper, nor were the journals and newspapers being printed at the sometimes twice-daily rate witnessed in the European press in the nineteenth century. Nevertheless, the profound changes that the form of the newspaper or journal inaugurated in the lives of its readers and the sorts of imaginings it invited through a shared, "mass ceremony" of reading, point to the deep shift taking place with the explosion of press activity in Beirut in the early 1870 s.

Readers anticipated that journals and newspapers would print material that would be "useful" to them as they participated in a burgeoning public sphere. As will be discussed later in this article, editors in 1870s Beirut would sometimes fail to meet these unstable expectations and would consequently announce a change of editorial direction. This preoccupation with the usefulness of reading resonates with Enlightenment notions that find their nineteenth-century complement in the British Utilitarian movement. As Richard Altick explains in his seminal study of the mass reading public, The English Common Reader, prior to the nineteenth century, books were "instruments of utility ... through them, men could learn the things they needed to know as businessmen and functionaries in civil government." He continues:

reading was inextricably linked with 'improvement' ... the demand was for handbooks of improvement, lessons in diligence and thrift, instruction in domestic relations, guides to godliness, popularized histories (always with useful lessons), translations, travel books, and books on science. ${ }^{17}$

Prior to the nineteenth century, periodicals did not hold a privileged space in the annals of useful reading. Yet in nineteenth-century England, Altick points to the growing focus on their role as instruments of progress: "even more important than books and pamphlets in the utilitarian program of enlightenment were newspapers." ${ }^{18}$

The perceived 'useful' role played by the European press in the lives of European readers served as a model for journals such as al-jinān in the 1870s. Arabic journals of this period reference foreign newspapers as sources for material, and there is evidence that a number of French and English periodicals were read by residents of Beirut in the late nineteenth century. ${ }^{19}$ In a short

17 Richard D. Altick, The English Common Reader: A Social History of the Mass Reading Public 1800-1900 (Chicago: University of Chicago Press, 1957), 26.

${ }^{18}$ Ibid., 131.

19 Among the journals cited by al-Najāh in 1871 are La Liberté, Le Moniteur universel, La Turquie, L'Indépendance Belge, L'Univers illustré, La Cloche, Paris journal, Figaro, Gaulois, La Couronne de Paris, La Patrie, and The Times. In addition to publications of the Roman Catholic 
essay concerned with the importance of reading entitled "Time is Gold" appearing in issue 9 of al-Jinān's first year, its author 'Abd al-Qādir Bey directs the journal's readership to the value of their time, cautioning them against wasting it. Citing a line of verse, "if your life were capital be warned against squandering it on what is not necessary," ${ }^{20}$ the author notes that "some people ignore this matter and thus waste their time on entertainment [malāhī] and playing backgammon and cards and the like and sitting around coffeeshops in which there is no use." ${ }^{21} \mathrm{He}$ contrasts this with gatherings in Europe, in which one member "asks those seated one by one about what they have read that day in the way of books and newspapers and what they benefited from that day." 22 This orderly recapitulation of the day's news and events resonates with the proceedings of the Syrian Scientific Society in 1868 and 1869, where members were encouraged to provide the group with useful updates on their newspaper reading. It also exposes the connection bourgeois residents of Beirut felt with a community of periodical readers across the Mediterranean in Europe after whom they modeled their own relationship with the Arabic and foreign press in 1870 Beirut.

"Time is Gold" is followed in the pages of al-Jinān by another brief essay expounding upon, as its title states, "The Usefulness of Reading." In this twocolumn article, Ilyās Effendī Habālīn notes that "it is said of us [Syrians] that we are rarely interested in anything other than the material aspect," and that what is generally considered useful is that which "is a means to amass much money quickly." ${ }^{3}$ He points out the need among Syrians for an "interest in eloquent books and refined newspapers which improve the value of pens," 24 citing al-Jinān as a prime example of this sort of edifying material. In discussions of the habit of reading, there is some equivocation across these early journals between a notion of usefulness that translates into material wealth, and a usefulness that aims to engender proper individual comportment through the acquisition of knowledge and cultured refinement. Habālin's concerned tone stems from "our lack of speed in [acquiring the habit] of reading

Church, al-Bashìr in 1870 and 1871 frequently references Le Moniteur universel, suggesting it was available with some regularity in early 1870 s Beirut. Daniel Bliss mentions reading copies of several foreign papers in Beirut, among them The Observer, The Congregationalist, and The Record. See Letters from a New Campus, 1873-74 (Beirut: American University in Beirut Press, 1994), 55; 62. Additionally, journals of the period regularly mention The Levant Herald, and cite Arabic journals published outside Beirut, such as al-Jawä $i b$, Wâdì al-Nî̀l, and al-Furät.

20 Al-Jinän 1:9 (1870), 277.

${ }^{21}$ Ibid.

22 Ibid.

${ }^{23}$ Ibid., 278.

${ }^{24}$ Ibid. 
periodicals [al-manshürat al-durriyyah]." ${ }^{25}$ This assertion itself, as well as the misspelling of 'periodical' as durriyyah rather than dawriyyah, suggest that the press in 1870 Beirut was very much in its formative stages. As in al-Jinān's "Time Is Gold," the implied comparison is with the perceived "progress" of the European press and its readership. Habālīn explains:

cultural $[a d a b i]$ reform gives rise to material progress... the people who are the most prosperous in terms of wealth and progress in material luxury are those who have reached the highest rungs of the intellectual ladder for they, due to the pleasure [they take in] dwelling upon essential events and scientific secrets, have produced from the reading of newspapers important material and financial results. ${ }^{26}$

The Arabic periodicals that emerged in 1870 Beirut offered themselves as edifying alternatives to a game of backgammon at the coffeeshop. A new form of socialization that centered upon the cultivation of the habit of reading at times held out the promise of not only edification but also wealth and progress along a European model. This move away from idle games to the habit of reading was indeed a prominent feature of the moneyed classes of Victorian England, as Altick attests. However, as he details, their wealth was not so much the result of their reading habits as an enabler of them:

'Cards, of course, were forbidden, and, while a game of bagatelle might be allowed, billiards, even in the home, were never mentioned.' In so scrupulous an atmosphere, the reading habit flourished. The place of the evening reading circle in Victorian middle-class family life is so well known that it need be merely mentioned here. How widespread the institution was, and how deeply it influenced the tastes of the children who grew up in such homes, is attested in countless memoirs. However, only the relatively well-to-do minority of the middle class, the merchants, bankers, professional men, manufacturers, and so on, could spend full evenings with their families and their books. ${ }^{27}$

The perceived reading habits of the European bourgeoisie provided readers of journals published in Beirut in 1870 with a model for comportment and a sense of imagined connection with their European counterparts. As Anderson points out, the bourgeoisie "was a class which, figuratively speaking, came into being as a class only in so many replications." ${ }^{28} \mathrm{He}$ develops this point, explaining that members of the bourgeoisie came

\footnotetext{
25 Ibid.

26 Ibid.

27 Altick, 86.

${ }_{28}$ Anderson, 77.
} 
to visualize in a general way the existence of thousands and thousands like themselves through print-language. For an illiterate bourgeoisie is scarcely imaginable. Thus in world-historical terms bourgeoisies were the first classes to achieve solidarities on an essentially imagined basis. ${ }^{29}$

In late 1870, al-Jinān featured an announcement regarding subscriptions for the coming year that reinforced the connection established in its pages between the attainment of bourgeois status and the cultivation of the habit of reading. The announcement praised the journal's readership for their attainment of a "fine level among the levels of the age of civilization and knowledge, for many had entered the garden [jinān] of culture [adab] and useful news by spending glittering gold and the essence of their precious time reading newspapers. " ${ }^{30}$ Salīm al-Bustānī’s fiction, serialized in al-Jinān, specifically addressed itself to the use value of the narratives for which its late nineteenth-century Arabic readership exchanged its "glittering gold." Matti Moosa, in his chapterlength study of Salīm al-Bustānīs fiction, highlights this central preoccupation with the "useful." 31 This theme repeats not only in the pages of his 1870 novel al-Huyām fí jinān al-Shäm (Love in Damascus Gardens), but also in the many other novels, short stories, anecdotes, and essays published in the journal before Salīm al-Bustānīs untimely death in the late summer of 1884 . In al-Huyām fì jinān al-Shām's penultimate installment, al-Bustānī explains to his readership the pedagogical use of novels: "we must show our faults and the faults of others for ourselves and for others by means of writing novels [riwāyat $]$, and show what is ugly and what is good by means of the description of the individuals whose stories we tell." 32 Fiction is here figured as an arena in which one can approach and consider a society's faults as they appear in the descriptions of fictitious characters, usefully serving as an outlet for autocritique and an impetus to reform.

Several pages earlier in this installment, we as readers discover that Sulaymān, the novel's protagonist, is not a native of Beirut, but rather moved to the city from Baghdad around 1864 because of the stories he had heard of the city's stunning progress. The narrative leverages this outsider's vantage point when he describes his disappointment at the sectarian divisions cutting across the city of Beirut and the surrounding region. The text offers an illuminating portrait of the sectarian reading habits in and around the city of Beirut in the late 1860s:

\footnotetext{
${ }^{29}$ Ibid.

${ }^{30}$ Al-Jinān 1:22 (1870), 687.

${ }^{31}$ Matti Moosa, The Origins of Modern Arabic Fiction (Boulder, CO: Lynne Rienner Publishers, 1997), 165.

${ }^{32}$ Al-Jinān 1:22 (1870), 702.
} 
[We] read newspapers and books of different tastes and inclinations, and as a result each of us is entrenched in the inclination of the people whose newspapers and books we read. And if we wanted to read others it would not be permitted by the leaders of our faction, rather it is planted in our thoughts that they are loaded with lies. And so our country has become divided into many divisions, especially because it has depended for the most part on reading French newspapers. And these newspapers are from many different factions... [with] the result that our factions almost outnumber theirs. ${ }^{33}$

Here, the divisions separating readers of French newspapers act as a cipher for the factionalization persisting in and around Beirut in the late 1860s, following the civil war of 1860. Though Buțrus al-Bustānīs pamphlet-like publication Nafìr Sürìya, appearing regularly in 1860 and 1861, addressed itself to "the sons of the nation," the repeated call for unity in the wake of the events of 1860 suggests that divisions still ran deep. Arabic newspapers such as the Beirut-based Hadiqqat al-Akhbār, the Istanbul-based $a l-J a w a \vec{a} i b$, and the Cairobased Wādi al-Nìl were available and read in 1860s Beirut and its environs, yet the factionalized readership that Sulaymān describes, dependent upon the French press for news, represents a moment before the emergence of a locally based and imagined public sphere.

The explosion in Arabic periodical publication in 1870 and 1871 in Beirut marks the emergence of this locally based and imagined public sphere. The journals published in the early 1870s in Beirut reveal that while the city and the region remained divided into factions, readership of the city's new journals extended across sectarian lines, giving rise to an atmosphere of civic debate. For instance, the Jesuit-published journal al-Bashir, founded in September of 1870 , regularly quotes in its first years from articles published in al-Jannah, al-Jinān, al-Jawäib, and the American Protestant journal al-Nashrah alUsbüiyyah, which replaced the earlier and more irregular al-Nashrah al-Shahriyyah in 1871. In the last weeks of 1871, al-Nashrah al-Usbü iyyah announced that the Jesuits would be publishing a tract or risälah, and that the Protestant missionaries would be publishing their own response. ${ }^{34}$ While the Jesuit authors responsible for publishing al-Bashir and their Protestant counterparts involved in putting out al-Nashrah al-Usbüiyyah often take profound issue with each other, nonetheless their debate in print suggests a departure from the factionalized portrait Sulaymān paints of late 1860s reading habits in Beirut. What emerges in this period is instead a city of bourgeois readers, connected to Europe through the press but also engaged in heated, printed discussion with their local bourgeois counterparts from Beirut as well as other

\footnotetext{
${ }^{33}$ Ibid., 700.

${ }^{34}$ Al-Nashrah al-Usbüiyyah 1:49 (1871), 8.
} 
cities in Greater Syria and the Arab world. The emerging press, then, plays a role in consolidating a constituency of bourgeois readers. In May of 1871, the bi-weekly journal al-Najăḥ ran an allegorical short story entitled "al-Wațan wa-l-ittifāq" ("Nation and Agreement") that dramatized the relationship between Beirut's periodicals and their readership. In the story, the fatherly character al-Wațan (or 'nation') discusses his use of the newspaper as a "mouthpiece" [lisān] for his message of unity. ${ }^{35} \mathrm{He}$ articulates one of the central roles envisioned for the burgeoning press of 1870s Beirut: the formation, addressed above, of what Anderson calls a "mass ceremony" of readers.

However, "al-watan" at this time is a loose signifier, in many ways paralleling the contours of the reading public of Arabic newspapers printed in Beirut. For as the noted author Fransīs Marrāsh explains in an article entitled "alWațan" in the journal al-Zahrah in 1870, "a person's nation [watan al-mar'] is his home in relation to his quarter [mahallatihi]. And his quarter in relation to his city [madinatihi]. And his city in relation to his qutr. And his qutr in relation to the rest of the aqtār [plural of qutr]." ${ }^{36}$ The very difficulty of translating a late-nineteenth century use of qutr, a word that can mean region, district or country, continues to resonate in the early twenty-first century. That Marrāsh is a resident of Aleppo, writing in a journal published in Beirut, further dramatizes his assertion on the next page of this essay: "we are a people without a nation." ${ }^{37}$ Denouncing the use by many of his peers of foreign languages and the adoption of "strange foreign customs," 38 Marrāsh calls for the use of Arabic as a way to bridge the differences between his people. Despite his frustration at this self-modeling after foreigners, however, Marrāsh nonetheless holds "the French nation [al-ummah al-faransäwiyyah]" 39 out as a template for unity among his people. Yet the factionalization of French newspapers and their readership discussed in the pages of al-Jinän suggests that the French nation might not have been the glimmering model that Marrāsh seemed to have in mind. The fiction that Salīm al-Bustānī serialized in al-Jinān offered itself as a compelling means through which the newly forming bourgeois readership in Beirut and its environs could sort through this conflicting network of "strange foreign customs" while still benefitting from ideas such as nationalism and progress.

Salīm al-Bustānī's fiction, like the laudatory language of the al-Jinān announcement contained in issue 22 of 1870 that praised the audience's use

35 Al-Najāh 1:39 (1871), 619.

36 Al-Zahrah 1:24 (1870), 186.

37 Ibid., 187.

38 Ibid.

39 Ibid., 188. 
of both their money and their time, invited bourgeois readers to imagine and participate in local models of proper reading habits and intellectual comportment. In so doing, it provided a bridge between the idealized model of Europeans and their literary practices, and the newly forming reading public of late nineteenth-century Greater Syria. Reading appears in al-Huyām fì jinān alShām as not only a path to individual edification, but also as a public activity reminiscent of the meetings of the learned societies and models of reading espoused in the short articles appearing in al-Jinān in its first year. When Sulaymān, the story's protagonist, finishes his dinner one night and leaves the tobacco smoke-filled dining room of the Damascus hotel where he is staying, he joins a French woman and several other foreign ladies in the hotel's sitting room. There they spend the evening talking, singing, "and reading some books and newspapers (jarä id)." ${ }^{40}$ Other men join them following their postprandial smoke. The male protagonist favors the company of foreign women who enjoy reading and edifying discussion over that of men from whose mouths "the hateful smell of tobacco springs." 41 The narrator instructs the bourgeois reader in the meaning of this mixing of the sexes "according to the foreign manner." He notes that "the attainment by one unaccustomed to it of that sort of closeness with the fairer sex would make him very proud and boast of this distinction and imagine things that perhaps were unlikely to occur." 42 The narrator educates his male audience members in the proper manner of conduct for this situation, placing the emphasis not on the romantic implications of such an encounter but rather on the enlightening conversation and opportunity for reading that it afforded. This scene may well have come to mind when readers of al-Jinān encountered, six issues later, 'Abd al-Qādir Bey's narration of a European intellectual gathering, featuring a measured discussion of the day's journals and news.

Indeed, al-Huyām fì jinān al-Shàm reveals reading to be the very impetus behind the European hotel guests' presence in Syria, exposing the web of connections imagined through reading that link the international bourgeoisies. In the course of his evening discussions with the European travelers, Sulaymān discovers that he shares with them a desire to visit the ruins of Tadmur, the Arabic name of the ancient city Palmyra. After their visit to the ruins, Sulaymān and the foreigners, along with their contingent of servants and guides, battle against and are ultimately captured by a Beduin tribe. They are rescued from their captivity by Sulaymān's beloved, Wardah. Wardah is in the

\footnotetext{
40 Al-Jinān 1:3 (1870), 91.

${ }^{41}$ Ibid.

${ }^{42}$ Ibid., 90.
} 
position of moderator and translator between the French-speaking foreigners and the Beduin leaders who have captured and taken a particular liking to her. The Beduin do not understand what the foreigners are doing in the region; Wardah explains, "the travelers have come to our country to look upon it, because in it are ancient ruins that clarify the histories that they read." ${ }^{43}$ Indeed, these foreigners are such avid readers that one of them, Madame Bilrūz, read a book as she rode her dromedary into battle four issues earlier. Sulaymān shares a love of reading history with the foreign travelers. When the group first comes within view of the ruins of Tadmur, Sulaymān notes, "it reminded me of what I had read in histories." 44

The usefulness of this sort of reading, popular among both European and local audiences, becomes clear when Monsieur Bilrūz narrates to the group the history of Tadmur upon their arrival at the ancient ruins. These histories serve as travel guides, an emerging genre in Europe at this time, with the first Baedeker guide to Syria and Palestine published in 1876. In keeping with this trend, the issues of al-Huyām fì jinān al-Shäm concerned with the visit to Tadmur read as a guide for those who might wish to make the journey themselves. A thorough itinerary is provided, replete with names of villages, landmarks, cardinal directions, and travel times, as is a list of the needed provisions, proper mounts, requisite number of servants, and required arms and tribal guides. Monsieur Bilrūz's lecture offers a detailed history of Tadmur and its famous queen Zanūbiyyā, complete with citations from the Bible. ${ }^{45}$ Sulaymān's first impressions of the ruined city, appearing earlier in the novel, serve as an introduction to the information Monsieur Bilrūz's speech provides.

While in the pages of al-Jinān the reading of books and journals is figured as a useful means of edification and proper bourgeois comportment, in alZahrah's 1870 serialized novel al-Shäbb al-maghrür (The Conceited or Tempted Youth), reading is primarily a private activity for entertainment and relaxation. This duality is central to debates surrounding the proper comportment of the emerging bourgeoisie across Beirut and its environs in the late 1860s and early 1870s. Indicative of the uncertain status of bourgeois reading habits, an illicit, clandestine aspect haunts the entertaining and relaxing side of read-

\footnotetext{
${ }^{43}$ Al-Jinān 1:12 (1870), 377.

${ }_{44}$ Al-Jinān 1:6 (1870), 184.

${ }^{45}$ Salīm al-Bustāni appears to have found the history of the ancient city of Tadmur particularly relevant to readers of al-Jinān in the early 1870s; the following year he set his first serialized historical novel in that ancient city during its days of splendor, calling it Zanübiyyä after the city's queen and one of the novel's protagonists. Following in al-Jinän's footsteps, the Protestant weekly al-Nashrah al-Usbüi iyyah, first appearing in January of 1871, inaugurated a series of descriptions and histories of ancient and biblical cities of the Levant and Holy Land in its fourth issue with a history of Tadmur.
} 
ing in al-Shābb al-maghrūr, exposing anxiety surrounding issues of class and gender in and around Beirut at the time.

The readers of al-Zahrah's 1870 novel al-Shābb al-maghrūr are introduced in its first installment to an unnamed narrator who travels in June of 1866 from Beirut to Damascus, where like Sulaymān he too stays in a hotel. He soon meets Khalil, and much of the novel is his narration of Khalil's tale to a fellow traveller on the return trip from Damascus to Beirut. This traveller turns out to be Faḍlū, whose fiancée Anīsah is a character in Khalīl's tale, for she befriended Khalīl while she and Faḍlū were staying in Damascus. Khalīl eventually leaves the city despite Anīsah's protestations, travelling around Syria before returning to Damascus with a woman he has fallen for named Ghirrah and her mother Fitnah. From that point forward, the novel is the story of the narrator's attempts to help bail Khalil, the conceited, tempted youth of the novel's title, out of the debts he has incurred as a result of Ghirrah and her mother's penchant for extravagance, which turns out to be his demise. He is left bankrupt and wandering the streets of Damascus in the penultimate installment of al-Shäbb al-maghrür. Though he came from a wealthy family living in Beirut, the speed with which he falls into debt and ill repute stands as a striking warning to readers of the vulnerable, fragile position of a tempted bourgeois youth given to delusion in late nineteenth-century Syria.

Not only do anxieties surrounding bourgeois status hover over al-Shābb almaghrür, so to does the intersection of literacy with changing gender relations. In al-Shäbb al-maghrür's second installment, the narrator returns to his hotel room in Damascus to get dressed for the evening outing he has just arranged with a man from Aleppo whom he met over dinner. As he begins to change his clothes, he narrates:

I turned to my bed, and it appeared as if it were saying to me, 'Come here, delight in the relaxation of sleep and the pleasure of dreams.' There was, furthermore, beside the bed a book containing some literary stories [qisas adabiyyah], which I heard calling to me as if its pages were saying 'Here is calmness and pleasurable reading (muțāláah). ${ }^{36}$

He undresses and crawls into bed with the book, and must beg his new friend's forgiveness when the latter comes knocking a few moments later. This image of reading as evening entertainment appears again in the thirteenth issue of al-Shäbb al-maghrür. At this point in the serialized novel, the un-named narrator of the second issue has faded from view, as he follows along with us the first-person narrative of Khalil, a man he met in a Damascus garden while out

46 Al-Zahrah 1:2 (1870), 16. 
for a walk. Earlier in the installment, Khalì left his keys for his neighbor Anīsah, the young, engaged woman who is most upset at Khalil's imminent departure from Damascus. She lets herself in after Khalil has gone to sleep; when he awakes in the night, he finds her sitting beside his bed, reading. She explains: "In order to entertain myself I picked up this book to read (uțālia)." "47

The initial meeting of Khalīl and Anīsah traces back to a letter Khalìl dropped one night while passing Anīsah on the stairs. Searching everywhere in his room, Khalil finally finds it by his door; however, the letter now bears a black seal with the letter nūn on it, while he always seals his letters in red. The next morning he finds out the names of his neighbors, Faḍlū and Anīsah, and shortly thereafter Anīsah greets him in the hallway and then comes to his room in order to borrow something with which to re-light their fire, which has died out. During a conversation that stretches across several installments of the novel, Khalil repeatedly thinks she is about to bring up the letter, creating an air of suspense around the mysterious circumstances of its reappearance. Finally, in the tenth issue, she does. Swearing that she never read it, Anīsah explains that she was interested in it because she thought it might be "the writings of a woman." ${ }^{48} \mathrm{He}$ insists that she must have read it, citing the changed seal; she laughs, telling him that she did that so that he would come and speak to her. Far from the edifying nature of reading depicted in the pages of alHuyām fì jiñann al-Shàm, reading here becomes a clandestine activity, staged by the engaged Anīsah and communicated via a coded language of seals, serving as what she terms "'a means of flirtation" " with her neighbor Khalìl. ${ }^{49}$

Letters, albeit of a less clandestine sort, play a central role in the continuation of the plot of al-Huyām fì jinān al-Shām. Sulaymān had spied upon and quickly fallen in love with Wardah in a garden in Damascus before encountering her on the sight-seeing excursion to Tadmur. Later in the novel, the two have just managed to escape from the Beduin tribe that captured them nearby Tadmur when Wardah is captured again, this time by a band of robbers, before being taken aboard a pirate ship. The narrator learned of these events when he met Sulaymān one day on Mount Lebanon. Following this initial meeting, Sulaymān sends a series of letters to the novel's author updating him on his progress, with the final letter coming from Italy where Sulaymān and Wardah finally married. In a sophisticated meta-narrative device, these letters are sent to a character called Salīm al-Bustānī.

\footnotetext{
${ }^{47}$ Al-Zahrah 1:13 (1870), 104.

${ }^{48} \mathrm{Al}$-Zahrah 1:10 (1870), 80.

49 Ibid.
} 
Reading these two sometimes epistolary novels side-by-side focalizes the formal similarity between an installment of a novel and a letter, both of which might arrive in the same post. ${ }^{50}$ The anticipation familiar to readers from receiving letters is here tied to that experienced as one awaits the next issue of al-Zahrah or al-Jinān. In al-Huyäm fì jinān al-Shäm, written correspondence is the very means by which the plot is sustained after the narrator and protagonist part following their meeting in Issue 16 beneath a cedar on Mount Lebanon overlooking the Mediterranean Sea. The two exchange not only letters, by means of the French and Austrian mail, but also telegrams, as Sulaymān's travels take him in the direction of Izmir, then on to Crete and finally Napoli. The letters and telegrams are crucial to the novel's plot and character development. It is through his signature at the end of a letter that we discover that the narrator of al-Huyäm fí jinān al-Shäm is none other than Salīm al-Bustānī, and, in the final installment, that the protagonist who has up this point remained nameless is Sulaymān Khālid. The two employ letters and telegrams not only to communicate about Sulaymān's travels during his search for his beloved Wardah, but also to enable Sulaymān to conduct economic transactions while far away from the financial institutions of Beirut. Their correspondence thus enables the tale to continue, as Salim sends Sulaymān funds, and Sulaymān sends Salīm, and thus al-Jinān's expectant readership, the latest news of his adventures in pursuit of Wardah.

At one point in the nineteenth installment of al-Huyām fí jinān al-Shäm, Salìm has not heard from Sulaymān for three months, despite the many letters Salim has sent to every port he can imagine his friend may have arrived in. Salìm begins to fear for his friend's fate, and the story al-Jinän's readership has been following threatens to come to an unresolved end. Finally, Salìm comes upon a group of sailors on the shore of the Mediterranean just north of Beirut, and discovers that they were on a ship with Sulaymān, and so the narrative continues. The narrative threat represented by a suspension of news via letter or telegram reappears in the novel's final installment. Al-jinann's readership discovers that they, along with their narrator, had been awaiting news of the tale's conclusion. As Salim explains: "the beauty of a novel is in the quality of its ending. After thinking about that for a long time I was determined not to publish this novel" without news of how Sulaymān's search for Wardah finally concluded..$^{51}$ The update comes in a letter from Sulaymān and Wardah in

${ }^{50}$ On the dynamics of epistolarity in intellectual circles of the Nahdah, see Boutheina Khaldi's "Epistolarity in a Nahḍah Climate: The Role of Mayy Ziyādah's Letter Writing" in this issue of the Journal of Arabic Literature, which addresses Mayy Ziyādah's letter writing as an extension of her salon in early twentieth-century Egypt.

${ }^{51}$ Al-Jinān 1:23 (1870), 732. 
Napoli that ties together the remaining loose narrative strands. Letters and telegrams in the pages of al-Huyām fì jinān al-Shām thus provide a narrative form and structure within the serialized novel which allows Salīm al-Bustāni to stage the relationship between reader and text, using familiar epistolary models to educate readers and potential future writers in the production of narrative suspense.

Among the journals that may have arrived in the mail in 1870 alongside al-Jinān was, of course, al-Zahrah. While the early issues of al-Zahrah's alShäbb al-maghrür drew attention to the relationship between this circulation of letters and the creation of narrative suspense, the novel then shifts its emphasis to a more acute romantic tension. In the eleventh installment, the female neighbor Anīsah begs the protagonist Khalil not to leave, so that they can have fun together. Khalìl warns her that "'this sort of entertainment (tasliyah) might give birth to thinking on my part of which you are unaware." "52 She responds that this is not a fear, and they discuss what might happen if it does become an issue, to which she responds that they will have to then refrain from their evening chats. He decides that it would be better for him to travel as planned, and she says: "If you do, I will be encompassed by intense boredom." "53 The conversations taking place over the past several issues between Khalì and Anīsah, punctuated both by weekly breaks and the looming mystery of the changed seal, create a sense of illicit romantic tension that leaves the reader uncertain yet anticipating what will happen next. The novel's bourgeois readership is implicitly asked to imagine a situation in which Khalì does not travel as planned. The text insinuates the thoughts Khalil might have in that event, and as the possibility is left suspensefully hanging over four issues, al-Zahrah's readers would have spent nearly a month speculating as to what was to come of this affair.

Both al-Shäbb al-maghrūr and al-Huyām fì jinān al-Shàm sustain an atmosphere of suspense over the course of the year 1870. Over and over again, installments end with a character in mid-sentence, or a dramatic scene is played out over the course of a number of issues. The emergence of frame tales and embedded narratives keeps the readership unsure of what might come next and of what new characters might appear, while also creating pregnant pauses in the narrative. Linda K. Hughes and Michael Lund direct us to the "delight in 'more to come," " which readers of the Victorian serial encountered at the end of each issue. ${ }^{54}$ Their study links this delight to a nineteenth-

\footnotetext{
52 Al-Zahrah 1:11 (1870), 88.

53 Ibid.

${ }^{54}$ Linda K. Hughes and Michael Lund, The Victorian Serial (Charlottesville, NC: University Press of Virginia, 1991), 6.
} 
century confidence in progress, a word (taqaddum) that appears frequently in al-Jinān's first issue. ${ }^{55}$ Building off the work of N. N. Feltes in his Modes of Production of Victorian Novels, Hughes and Lund direct us to the manner in which the serial form "harmonized in several respects with capitalist ideology," not least of all in the "assumption of continuing growth." 56 Their observations are no less pertinent to Beirut in early 1870, when the silk trade was still booming, banks and schools were flourishing, and novel ideas of bourgeois life were filling the public sphere.

In her book The Serious Pleasures of Suspense: Victorian Realism and Narrative Doubt, Caroline Levine treats the nineteenth-century debate around suspense among Victorian authors and thinkers, making an argument about the interactions of a bourgeois readership with suspense-generating texts such as the serialized novel. In a survey of previous theorizations of suspense, Levine explains:

It has become something of a commonplace to presume that suspense fiction reinforces stability, activating anxiety about the social world only in order to repress that anxiety in favor of unambiguous disclosures and soothing restorations of the status quo. But it was not always so. This book makes the case that Victorian writers and readers understood suspenseful narrative as a stimulus to active speculation. ${ }^{57}$

While the regular repetition of the coda "the remainder is to come" at the end of each installment of a serialized novel such as al-Shābb al-maghrūr or alHuyām fí jinān al-Shàm may well have resonated with comforting notions of progress and continuing economic growth in the 1870s Beirut where they were published, Levine's intervention suggests that the suspense generated in the pages of these texts simultaneously invited readers to actively wonder about, and also perhaps to fear what was to come.

Also noting that the serial form and the deployment of suspense produced a sense of speculation and anxiety among bourgeois readers, Feltes goes on to identify within this audience a reader who in turn produces a degree of uneasiness among authors and publishers: the unknown reader. ${ }^{58}$ Feltes highlights the centrality of the serial's relationship with its readership in creating what he

\footnotetext{
${ }^{55}$ For more on the multiple Ottoman and European discourses of reform informing narratives of progress in late nineteenth-century Beirut and Mount Lebanon, see Makdisi, especially "Chapter 2: The Gentle Crusade," and "Chapter 5: Reinventing Mount Lebanon."

56 Ibid., 4.

${ }^{57}$ Caroline Levine, The Serious Pleasures of Suspense: Victorian Realism and Narrative Doubt (Charlottesville: University of Virginia Press, 2003), 2.

${ }^{58}$ N. N. Feltes, Modes of Production of Victorian Novels (Chicago: University of Chicago Press, 1986), 94.
} 
terms in the Victorian context a "mass bourgeois audience." ${ }^{99}$ While the scale of publication was considerably smaller in late nineteenth-century Beirut than in London, there is in evidence a similar concern in the Beiruti periodicals of this period with fostering a growing readership. Attempting to expand their readership, while also keeping their audiences interested and in suspense, Beirut-based journals along with their audiences sought to identify and define who their readers were. The list of subscribers printed on the inside cover of a journal such as al-Jinān only begins to address this question, for any literate member of a subscriber's household might read the journal, just as a subscriber might pass an issue on to a friend or read an interesting story or anecdote aloud at a gathering. Indeed, al-Huyām fí jinān al-Shäm stages a scene of the narrator reading aloud from a page of his journal to a close friend, suggesting just the sort of social setting in which written stories might be shared aloud. ${ }^{60}$

From the first installment of al-Huyām fì jinān al-Shàm, the novel's readership is parenthetically addressed by al-Bustānī as he defines words within the text, perhaps most notably when we are informed that "illiterate [ummi] " means "not knowing how to read or write." 61 This definition in particular betrays an anxiety over the uncertain linguistic levels of an audience new to the periodical and the narrative form of the novel, yet also reveals a willingness on al-Bustānī's part to accommodate and nurture this growing readership. In "Khuṭbah fī ādāb al-'Arab", Salīm al-Bustānī’s father Buțrus spoke of the state of literacy in the city of Beirut in the first half of the nineteenth century. While allowing some room for the dramatics of rhetoric, his anecdotal comments convey his sense of the low literacy level in the city only two generations earlier: "I would walk in the markets of this city... and search with effort for one who was able to read... or as they say decipher a name." ${ }^{62}$

As the serialized installments of al-Huyām fì jinān al-Shàm gain momentum over the course of the year 1870, Salīm al-Bustānīs engagement with his audience's lexical abilities falls away in the text. In a later issue, the parenthetical address to the reader reemerges for a brief moment; however, this time its concern is not at the level of the readership's vocabulary, but rather their literary acumen, offering a different slant on the ability to "decipher a name." Unsure of an audience's ability to identify a character due to a shift in narrative voice, the twentieth installment provides the reader with a parenthetical gloss:

\footnotetext{
59 Ibid., 17.

${ }^{60}$ Al-Jinān 1:23 (1870), 732.

${ }^{61}$ Al-Jinān 1:1 (1870), 27.

${ }^{62}$ Buțrus al-Bustānī, 113.
} 
"as for the Captain General (or Wardah's beloved)." ${ }^{63}$ A reader's failure to make out that the Captain General is none other than Wardah's beloved by this point in the twentieth installment would have meant that nearly all of the previous installment would have read as an unrelated adventure tale rather than as a critical scene in the love story that the novel has been tracking since the second installment. This parenthetical address thus serves to not only identify a character, but also provides a lesson in literary form, directing the emerging readership to the internal cohesion of the novel and the art of deciphering the names within it.

The category of the unknown reader also resonates with anxiety surrounding the uncertain place of women within the growing readership in and around Beirut. Though Roger Allen can confidently state in the context of 1880 s and 1890s serialized fiction in Egypt that "women were, as in the European model, primary readers of serials," ${ }^{64}$ for early 1870 s Beirut-based periodicals, this was considerably less clear. A short story entitled "Hanrī wa Amīliya" ran in issues 12 and 13 of al-Jinān in 1870 and was attributed to one Adilayd Bustānī. The story was narrated in the third person, and at the very end of the second and final installment the author leaves behind the world of the narrative to address the readers of al-Jinān, writing: "If there are some ladies joining the gentlemen in reading al-Jinān, the gentlemen are entitled to something from the pure, refined pen of the ladies. And thus has the door to al-Jinān [the gardens] been opened to the ladies." ${ }^{65}$ The language of this invitation to literary submissions is ambiguous, for it leaves the reader to wonder if in fact the preceding story is the first story "from the pure, refined pen of the ladies." It leaves open the possibility that perhaps the unusual name of Adīlayd Bustāni has been adopted by Salīm al-Bustānī, an advocate of women's education and, as we have just seen, an advocate of women's participation as readers and now writers in the burgeoning press of 1870s and 1880s Beirut. The possibility that Adilayd is a pen name is reinforced by the story itself, in which a woman goes out for a walk dressed as a man so as to fool an audience of onlookers. Wardah of al-Huyām fí jinān al-Shàm, figured as a Syrian woman who can read and write not only Arabic but also French, likewise masquerades as a young man in the pages of the novel. The open door of al-jinann's lettered world leaves male readers unsure as to whether there are already women readers and writers among them, or if they are still hovering at the threshold. This

63 Al-Jinān 1:20 (1870), 634.

${ }^{64}$ Roger Allen, "Literary History and the Arabic Novel," Twayne Companion to Contemporary World Literature: From the Editors of World Literature Today, Pamela A. Genova, ed. (New York: Twayne, 2003), 115.

${ }^{65}$ Al-Jinān 1:13 (1870), 407. 
note of uneasiness and equivocation resonates with the uncertainty surrounding Feltes' notion of the unknown reader, yet it is interesting to note that in narratives in both al-Jinān and al-Zahrah, it is specifically a female reader who produces a pronounced sense of anxiety in the text.

Al-Jinān's solicitation of the work of women writers directs us to a key phenomenon at the heart of the explosion of journalistic activity in Beirut, Mt. Lebanon and Greater Syria, and later Egypt, at the end of the nineteenth century: the transformation, as Clifford Siskin discusses in another context, of readers into writers. This transformation highlights the formative significance for modern Arabic literature of the early press in Beirut and the narrative forms it adopted and chartered. As Siskin observes in the case of the proliferation of English periodicals in the mid-eighteenth century:

when we keep in mind the historical sequence I've described above-the rise in writing occurring after the rise in the literacy rate-we realize that one fundamental form of change at issue was the transformation of reader into writer. [...F] ormerly passive [readers] become participants in, and partial producers of, what they consume. ${ }^{66}$

Indeed, in a one-page announcement of the new journal al-Jinān in December of 1869 , Buțrus al-Bustānī writes that a primary factor motivating the journal's founding was the desire to "activate authors to present to us what they have in the way of useful lessons." ${ }^{67}$ In early May of 1871, al-Najāḥ ran a short story sent in by one of its readers entitled "Wadī and Nuzha," while several weeks later it published a short poem written by an eleven year-old reader, as well as an advertisement for a new novel entitled Hifz al-widäd wa nakth al'uhüd [Preserving Love and Breaking Commitments], placed by its author Jirjī Yanī. ${ }^{68}$ The weekly American Protestant journal al-Nashrah al-Usbü iyyah, first published in $1871,{ }^{69}$ printed not only articles and sermonizing narratives in serial form as well as lists of religious books available for purchase through the journal, but it also regularly awarded prize money for essays from its readers, and printed the names of the winners of their Biblical trivia contest. The final page of issue 23 of 1872 ran a call for essays on honesty, while two weeks later issue 25 announced a monetary prize for the best essay on the spread of

${ }^{66}$ Clifford Siskin, "Epilogue: The Rise of Novelism," Cultural Institutions of the Novel (Durham, NC: Duke University Press, 1996), 427.

${ }^{67}$ Included at the beginning of the bound volume of al-Jinān (1870) held at the American University in Cairo.

${ }^{68}$ Al-Najāḥ 1:33 (1871), 523-25; al-Najāḥ 1:38 (1871), 601; 604.

69 See Ayalon and Tarrāzī for more on the early publishing efforts of the American mission. 
gambling. ${ }^{70}$ Letters from readers were also regularly published in al-Jinān, al-Zahrah, al-Najäh, and al-Nashrah al-Usbü iyyah as well as in other journals of the period. These publications clearly envisioned their expanding audiences as not only readers but also potential future writers, with circulation for many of the period's journals extending far beyond Beirut and Mount Lebanon to Baghdad, Cairo, Istanbul, Tunis, and even Manchester, Marseilles, Calcutta, and eventually New York. Some readers would go on to found their own journals in Beirut, Alexandria, Cairo, New York and no doubt elsewhere, such that the literary themes and forms printed in the pages of early 1870 s journals such as al-Jinān and al-Zahrah became part of the literary education of writers throughout the Arabic-speaking world.

While many critics of modern Arabic literature make reference to 1870 s and 1880s Beirut in their histories of the modern novel, there is a strong tendency to relegate this tremendously rich and yet seldom read body of journals to a passing comment about a Syrian émigrés past. A superficial glance is cast at 1870s and 1880s Beirut as critics rush on to Egypt at the turn of the century, which in the process crystallizes as the literary epicenter of early modern narrative fiction. ${ }^{71}$ Paul Starkey's recent study reflects this critical current; he writes:

The period covered by the present chapter, 1880-1933, represents a crucial one in the emergence of modern Arabic narrative in the form of the novel and short story as usually understood in the West. Perhaps more than any other chapter, it will be dominated by developments in Egypt-though... Syrian émigrés also played a crucial, contributory role. ${ }^{72}$

A sustained focus on the literary forms published in the Beirut journals of the 1870 s and 1880s uncovers the literary formation of many of these Syrian émigrés - readers who in turn became writers in the late nineteenth and early twentieth centuries in Syria and Egypt as well as in diasporic Arab communities in Europe and the Americas. Too often these pivotal decades are distilled down to a brief mention of Salīm al-Bustānī without sustained attention to the literary forms or intellectual atmosphere of 1870 s and 1880s Beirut. This phenomenon is evinced by Roger Allen when he explains that Egypt, "now quickened by the new arrivals from Syria, became the fullest and most often

${ }^{70}$ Al-Nashrah al-Usbüiyyah 2:23 and 2:25 (1872).

71 In English, the work of Sabry Hafez, John A. Haywood, Matti Moosa, Shmuel Moreh, and Stephen Sheehi represents the notable departures from this mold. In Arabic, the work of Shākir Mușțafā, Muḥammad Yūsuf Najm, Ibrāhīm al-Sa āfīn, and 'Abd al-Raḥmān Yāghī concerns itself with the literary history of late nineteenth-century Beirut.

72 Paul Starkey, Modern Arabic Literature (Edinburgh: Edinburgh University Press, 2006), 97. 
cited example of intellectual developments in the early decades of the twentieth century. Our concentration in what follows on trends in Egypt reflects this tendency." ${ }^{\prime 3}$ We see a similar critical bent in the work of M. M. Badawi, particularly in his overwhelming focus on Egypt in the sections of both Modern Arabic Literature and the West and A Short History of Modern Arabic Literature addressing the origins of the Arabic novel. ${ }^{74} \mathrm{~A}$ trademark in this literary-critical trend is a discrete focus on Jurjī Zaydān as perhaps the example par excellence of the Syrian émigrés contribution to the history of the Arabic novel.

It was not until 1883, however, that Zaydān left Beirut for Egypt. Indeed, Zaydān, who serialized a large number of original Arabic novels in his Cairobased journal al-Hiläl begun in 1892, identifies himself as part of a lineage of writers, with the Syrian author Fransīs Marrāsh and Salīm al-Bustānī preceding him in the literary project of the modern novel. ${ }^{75}$ Yet as 'Abd al-Muhsin Țaha Badr argues in his seminal study of the Egyptian novel, it is difficult "to pinpoint the source out of which Jurjī Zaydān developed the plot of his novels, because the taste of popular audiences is in accordance in all environments with their preference for adventure and their celebration of elements of suspense and surprise." ${ }^{" 76}$ Ibrāhīm al-Sa āfin develops this point further in his study of the Syrian novel, originally written under the supervision of 'Abd alMuhsin Taha Badr as a doctoral dissertation later published in book form. ${ }^{77}$ Al-Sa āfin argues that "[the narrator] knew with certainty that his audience's taste had been raised on popular literature going back for generations," and that this audience had a unique "connection... with this narrative heritage." 78 This assertion becomes one of central importance when the focus shifts from the individual author and his or her work and takes into consideration the importance of a collective narrative heritage to a newly forming reading public. While Salīm al-Bustānī and other authors of the period may be building off their familiarity with the form of the European serial novel in their deployment of suspense, pieces in the journals reference another suspense-generating narrative form perhaps more familiar to their readers: that of the popular Arabic narrative tradition, particularly works such as the story of 'Antar and Alf Laylah wa Laylah (A Thousand and One Nights). ${ }^{79}$

\footnotetext{
${ }_{73}$ Roger Allen, The Arabic Literary Heritage (Cambridge: Cambridge University Press, 1998), 72.

${ }^{74}$ M. M. Badawi, Modern Arabic Literature and the West (London: Ithaca Press, 1985), and A Short History of Modern Arabic Literature (Oxford: Oxford University Press, 1993).

${ }^{75}$ See Zaydān, 208-09.

76 'Abd al-Muhsin Țaha Badr, Tatawwur al-riwāyah al-'arabiyyah al-ḥadìthah fì Miṣr (18601938) (Cairo: Dār al-Ma ārif, 1976), 99.

${ }_{77}$ I thank Muhsin al-Musawi for informing me of this scholarly connection.

${ }^{78}$ Ibrāhīm al-Sa āfīn, Tatawwur al-riwāyah al-'arabiyyah al-ḥadìthah fì biläd al-Shäm: 18701967. (Beirut: Dār al-Mināhil, 1987), 26; 25.

${ }^{79}$ For a comparative perspective on the relationship of $A$ Thousand and One Nights to the
} 
In 1870, al-Zahrah wove this narrative heritage into an anecdote precisely about its audience's acute awareness of the working of suspense. The anecdote tells of a man who attended a storyteller's circle every night to listen to the story of 'Antar. One evening, "the storyteller read until 'Antar was captured by the Persians who imprisoned him and bound his legs and there he stopped speaking." 80 The man who had been listening to the story "went home sad and depressed," 81 eventually beating his wife out of frustration. Later that night he wandered in the markets trying to decide what to do, and finally it occurred to him to go to the home of the storyteller. There he begs the storyteller to get 'Antar out of prison, telling him that he will pay him as much as he regularly collects from an evening's audience "for I am unable to sleep." ${ }^{2}$ The storyteller agrees, "taking the book and reading him the rest." ${ }^{33}$ This anecdote printed in al-Zahrah reveals that the circulation and commodification of the story of 'Antar, like the serialized novel al-Shäbb al-maghrür that appears at the end of the issue, hinges on a form of narrative suspense that has a long history in the region.

A Thousand and One Nights and similar collections of tales work their way in not only through portraits of coffeehouse storytellers, but also in the advertising sections of journals in this period. In 1859, Buṭrus al-Bustānī painted a portrait of the storyteller who frequented Beirut's coffeeshops: ${ }^{84}$ "one with a hoarse voice and a good memory who has memorized some of the tales from the stories of Sindbad the sailor and Banī Hilāl and what is most similar to those among the stories present in the book $A$ Thousand and One Nights." ${ }^{35}$ New Arabic editions of the collection also appeared over the course of this period, and were advertised for on the back page of al-Jannah, a trade journal founded in 1870 by Buṭrus al-Bustānī and available in joint subscription with

novel in the nineteenth century, and to Aḥmad Fāris al-Shidyāq in particular, see Rebecca Carol Johnson, Richard Maxwell, and Katie Trumpener, "The Arabian Nights, Arab-European Literary Influence, and the Lineages of the Novel," Modern Language Quarterly 68:2 (June 2007): 24379. See also Muhsin Jassim al-Musawi, Scheherazade in England: a Study of the Nineteenth-Century Criticism of the Arabian Nights (Washingston, D.C.: Three Continents Press, 1981).

${ }^{80}$ Al-Zahrah 1:35 (1870), 275.

81 Ibid.

82 Ibid.

83 Ibid.

${ }^{84}$ For more on changes in public space during this period in Beirut, see Hans Gebhardt, Dorothée Sack, Ralph Bodenstein, Andreas Fritz, Jens Hanssen, Bernhard Hillenkamp, Oliver Kögler, Anne Mollenhauer, and Friederike Stolleis, eds, History, Space and Social Conflict in Beirut: The Quarter of Zokak el-Blat (Beirut: Orient Institute, 2005), especially the contributions of Ralph Bodenstein and Jens Hanssen; For a more theoretical approach to the changes in the organization of space during this period, see Timothy Mitchell, Colonising Egypt (Berkeley: University of California Press, 1991).

85 Al-Bustānī, 114. 
al-Jinān as well as Khalīl Sarkīs's Lisān al-Hāl upon its founding in 1877. The printed copies of $A$ Thousand and One Nights circulating among storytellers and the periodical reading class alike suggest an interest in the collection among literate members of the growing reading public, a public that as we have seen was increasingly shaping the content of journals as readers and writers. Prominent narrative techniques of $A$ Thousand and One Nights appear repeatedly in the novels and short stories of the 1870s and 1880s written in Beirut, among them the frame tale, the embedded narrative, and the repetition of a suspense-generating break between installments of a story.

In her book-length study of $A$ Thousand and One Nights, Ferial Ghazoul points out that Shahrazad, the infamous female narrator of this collection of tales,

is simply awarded a privilege that can be withdrawn at any moment, and it is precisely the feeling that she may not manage to please her audience-and, therefore, the hovering possibility of her condemnation [to death] — that makes The Arabian Nights a suspense story throughout its course. ${ }^{86}$

There is a burden upon Shahrazad, night after night, to "please her audience." In Husain Haddawy's translation of $A$ Thousand and One Nights, based on the text of the fourteenth-century Syrian manuscript edited in 1984 by Muhsin Mahdī, the first night ends with Shahrazad in mid-story, "leaving the King Shahrayar burning with curiosity to hear the rest of the story." ${ }^{87}$ The preoccupation that writers and editors such as Yūsuf al-Shalfūn and Salīm al-Bustānī had with appealing to their readerships in 1870 echoes Shahrazad's concern with "pleasing her audience." Salīm al-Bustānī left his readers in suspense from the first issue of al-Jinān, a tactic familiar from Shahrazad's manipulations of the king Shahrayar. The repetition of "the remainder will come" in the pages of an issue of al-Jinān held out a promise that left readers in suspense, and was, in form, not unlike the narrative technique propelling the proliferation of one night of storytelling into A Thousand and One Nights. Al-Shalfün's announcement at the end of al-Shābb al-maghrür suggests that this serialized novel was unable to please its readership:

Given that the novel al-Shäbb al-maghrür has come to an end, and many asked that we include a useful history in serialized form, from this point forward we will run the history of the war of the kings of al-Tabäba'ah in Yemen before Islam, taken from the book Jamharat al-'Arab (The Arab Populace), as it is likely that it will appeal to our esteemed subscribers. We likewise advise them that we will

${ }^{86}$ Ferial J. Ghazoul, Nocturnal Poetics: The Arabian Nights in Comparative Context (Cairo: The American University in Cairo Press, 1996), 85.

${ }^{87}$ Husain Haddawy, trans. The Arabian Nights (New York: W.W. Norton \& Company, 1990), 18. 
change the form of this our newspaper at the beginning of the new year by including useful foreign and local news that it will appeal to the reader to peruse, in accordance with what space will allow for, as we seek to spread public benefits to the audience. ${ }^{88}$

It was the end for the novel in the pages of the journal. Indeed, al-Zahrah never did see the new year, meeting with a sort of "condemnation to death."

Al-Shalfūn joined forces with Luwīs Ṣābūnjī, whose own 1870 journal alNaḥlah had likewise proved itself an unviable enterprise. The two published together a new journal entitled al-Najāh, which was also short-lived. In August of 1871, Șābūnjī, himself a Catholic priest, published the following announcement in the Jesuit journal al-Bashir:

We inform the dear audience that from the date of the first of this present month of August we have completely quit work on the journal [jurnāl] al-Najāh. And we have desisted entirely from involvement in its publication [...] from now on we will not pen a line or write an article in it. And we will not ever publish a political summary in it as we did previously. And we will not translate the novel [The Count of] Monte Cristo, which we had taken upon ourselves the responsibility of translating from French to Arabic while correcting those impolitenesses transgressing religion. In order to lift all responsibility from ourselves for the journal al-Najäh as well as responsibility for the impolite language in the novel Monte Cristo, the reading of which is forbidden to all Catholics by Rome due to its excessive crudeness against religion, we have issued this announcement without delay, written the 16th of August in the year $1871 .^{89}$

Like al-Zahrah and al-Nahlah before it, al-Najāh did not fulfill its readership's emergent narrative desires. The inability of novels such as al-Shäbb al-maghrür and the Arabic translation of The Count of Monte Cristo to conform to audience expectations for fiction's proper use and tone reveals the dynamic relationship between editors and authors and their readership in the early years of Beirut's burgeoning press. Readers' reception of narratives and of the journals publishing them deeply influenced the sorts of stories that would be told as the Beirut-based press continued to expand and influence readers across the Arabic-speaking world.

Many journals were successful in manipulating the suspense-generating model of serialization, putting out publications that harmonized with the demands of their readership or niche within the growing Arabic periodical market, both within and beyond Beirut and its environs. Among these journals was the Jesuit al-Bashir, which began publishing in September of 1870,

${ }^{88}$ Al-Zahrah 1:43 (1870), 314.

${ }^{89}$ Al-Bashìr 1:51 (1871), inside front cover. 
less than a year before Șābūnjī would announce the failure of his second journalistic enterprise. In addition to news of the Catholic Church and events in France, al-Bashìr's first five issues ran a fictitious, moralizing tale in serial form, entitled "Hikāyat qandīl al-mabad" (The Story of the Sanctuary's Lamp). Translated from the French, each installment, including its last, ended with the coda "the remainder will follow." ${ }^{\circ}$ Leaving the tale "Hikāyat qandīl al-ma bad" hanging unresolved, al-Bashīr's editors desisted from publishing fiction that year, instead printing articles on French and official Church news as well as Church bulletins and papal addresses, which it would often serialize over several issues. The journal would continue to publish into the twentieth century.

While al-Bashir eschewed the publication of fiction after its first early issues, Moosa observes of 1870 s and 1880 s Beirut that, generally speaking, fiction played a central role in the economic practicalities of the burgeoning press: "the readers were apparently pleased by what they read; many of them bought the journals primarily for the fiction they presented." ${ }^{11}$ While one evening of storytelling gains Shahrazad one day of life, for the journals being published in 1870s and 1880s Beirut, a compelling installment of a novel might help to not only retain readers but also to create new ones. Critic 'Abd al-Rahmān Yāghī points out that al-Jinān's inclusion of serialized fiction set a precedent that, through its popularity, created a demand for narrative among Arabic journal readers. ${ }^{92}$ While other Arabic periodicals before them had serialized translated European novels, al-Jinān's al-Huyām fï jinān al-Shäm and al-Zahrah's al-Shäbb al-maghrūr share the distinction of being the first original Arabic novels published in serialized form. In the case of missionary journals such as al-Bashir and al-Nashrah al-Usbüiyyah, as well as publications such as alJinān aiming for a less religiously based model of social betterment, a growing readership represented a larger audience for their message of change and progress. Yet it also crucially translated into increased economic viability, for as Ayalon notes of 1870 s and 1880s Beirut, "the press, like other commercial areas, involved competing for a limited market." $" 3$

The influence of $A$ Thousand and One Nights on the early decades of modern Arabic prose is a point over which there is much debate in Arabic literary critical circles. Intriguingly, the critics who tend toward a focus on Egypt in their histories of the early Arabic novel do not identify $A$ Thousand and One

90 Al-Bashīr 1:1 (1870).

91 Moosa, 97.

92 'Abd al-Raḥmān Yāghī, Al-Juhūd al-riwā' iyyah min Salīm al-Bustānī ilā Najīb Maḥūu (Beirut: Dār al-fārābī, 1999), 38.

93 Ayalon (1995), 37; see also Ayalon (2008). 
Nights as a central influence on modern Arabic prose in the late nineteenth century. Allen, for instance, argues that "another source of possible inspiration, the world's greatest collection of narratives, $A$ Thousand and One Nights, was... left out of the picture - at least during the early stages in the development of the novel in Arabic." ${ }^{\prime 4}$ He likewise quotes Charles Vial in the second edition of the Encyclopedia of Islam as stating that "'the modern qisssah [novel] owes nothing to Arab tradition. It is linked neither with the folklore of The Thousand and One Nights nor with tales of chivalry nor with narratives of adab." "95 After a discussion of various prose forms from the 'Abbasid period including $A$ Thousand and One Nights, Badawi for his part writes:

It cannot be claimed that any of these works contain even in a most rudimentary form the seed of a novel. Yet they all include certain narrative elements which could have served as a basis for novelistic development for the men who sought to infuse new life into Arabic literature in the latter part of the nineteenth century. This, however, did not happen. ${ }^{96}$

Badr in his study of the development of the modern Arabic novel in Egypt likewise does not see "popular literature" as playing a constitutive role in the early novel, despite its "fertile narrative and storytelling material, for not one of the intelligentsia was interested in it, but rather left it for the common people." ${ }^{77}$

Critics more steeped in the Syrian context, and in particular the serialized literary output emanating from Beirut in the 1870s and 1880s, see the issue somewhat differently. Of Salīm al-Bustānī’s fiction, Moosa observes: "the tone and narrative of his stories are reminiscent of The Thousand and One Nights."98 Shmuel Moreh too identifies an influence of $A$ Thousand and One Nights on Salīm al-Bustānī's writing, somewhat disdainfully explaining that "the style is one in which the plot is related by a sequence of verbs, which describe events without entering into details, and the reader's attention is engaged with the unfolding of a surprising and bizarre series of happenings." 99 Sheehi goes into more detail on the subject, writing that "many of [Salīm al-Bustānī’s] plots turn on happenstance or coincidence, reminiscent of high and low literature from The Story of 'Antarah, the maqamat genre, and al-Tanukhi's Faraj ba'd

\footnotetext{
${ }^{94}$ Roger Allen, The Arabic Novel: An Historical and Critical Introduction 2nd ed. (Syracuse: Syracuse University Press, 1995), 13.

95 Ibid. For more on the use of the term qișsah for novel, see Allen's discussion in Chapter 1.

96 Badawi 1985, 129.

97 Badr, 58.

98 Moosa, 161.

99 Moreh, 74-5.
} 
al-Shiddah to The Epic of Beni Hilal, A Thousand and One Nights, or even karakruz, the popular shadow-puppet plays." ${ }^{100}$ These three critics, all close readers of the serialized fiction of Salīm al-Bustānī, the most widely read author of original Arabic fiction during this period, appear to concur on the influence $A$ Thousand and One Nights had on his work.

Though the influence of narratives such as the story of 'Antar and $A$ Thousand and One Nights on the modern Arabic novel is much debated in Arabic literary critical circles, there is little debate on the impact that the European novel had on the emergence of the Arabic novel. In the context of late nineteenth-century readers of Arabic, Zaydān explains that

rather than the old tales like 'Antarah and A Thousand and One Nights,... [they] found the novels translated from the Europeans more believable, making them more appropriate to the spirit of the age, and so they welcomed them. Then the [Arabic] writers proceeded to compose their own works... in imitation of the Europeans ${ }^{101}$

Likewise, in his discussion of the early Syrian intellectuals, Muhsin al-Mūsawì cites Shākir Mușțafā as writing that the "'modern [Arabic] novel, born with the birth of modern Syrian society, ... was something new. It was not within the capacity of the [Arabic] heritage $(a l$-turäth $)$... to meet the needs of the new, developing bourgeoisie." 102 The narrative aspirations of a bourgeois reading class become clear in these accounts. Its members, though familiar with the older popular narrative heritage, found it insufficient for "the spirit of the age" during "the birth of modern Syrian society," and looked to Europe for models. European novels available in Arabic translation in Beirut in the 1870s and 1880s were works such as Alexandre Dumas, père's Le Comte de MonteCristo (The Count of Monte Cristo), Daniel Defoe's Robinson Crusoe, and Jules Verne's Cinq semaines en ballon (Five Weeks in a Balloon), while François Fénelon's Les Aventures de Télémaque (The Adventures of Telemachus) was published serially in translation in the late 1860s in Hadiqat al-Akhbār.

Adventure stories that follow the travels of their protagonists, these novels share much in common with tales such as those included in $A$ Thousand and One Nights, as noted by al-Musawi ${ }^{103}$ and scores of other critics. This was per-

100 Sheehi, 79.

101 Zaydān, 208

102 Muḥsin Jāsim al-Mūsawī, al-Riwāyah al-'Arabiyyah: al-nashảah wa-l-taḥawwul (Cairo: Al-Hay'ah al-Miṣriyyah al-'āmah li-l-kitāb, 1988), 23.

103 See for instance, Muhsin Jassim al-Musawi, Scheherazade in England: a Study of the Nineteenth-Century Criticism of the Arabian Nights (Washingston, D.C.: Three Continents Press, 1981). 
haps among the reasons that their translation so appealed to an Arabic-reading audience familiar with but weary of the story collection. Indeed, Yāghī points in his study of modern Arabic narrative to the manner in which "the spirit of A Thousand and One Nights was reflected in the adventures of Robinson Crusoe," drawing a parallel between the circulation of translated versions of $A$ Thousand and One Nights in Europe beginning in the early eighteenth century and the popularity of Defoe's novel in Arabic translation in the nineteenth century. ${ }^{104}$ In a similar vein, Allen directs the reader of The Count of Monte Cristo to the enormous number of references it makes to the Sindbad cycle, a group of stories often associated with $A$ Thousand and One Nights, as well as to other aspects of the collection itself. ${ }^{105}$

A discussion of the bound, Jesuit-sponsored Arabic translation of Jules Verne's Cinq semaines en ballon which appeared in late-nineteenth century Beirut, with a second edition already in print in 1883, will illustrate the intricate narrative weave in the Beirut journals of the 1870s and 1880s that shaped and was shaped by a newly forming bourgeois reading public. This translation joins a host of shorter pieces featuring hot air balloons in numerous journals. These merge discourses of scientific progress, contemporary economic relations, and the "formal realism" 106 of the modern novel with locally rooted modes of suspense and the fantastic, effecting a complex triangulation. On the one hand, the journals of 1870s and 1880s Beirut employ a popular Arabic narrative armature that not only appealed to Defoe, Dumas, and Verne, but also conformed to narrative conventions familiar to a local readership. On the other hand, these journals lean on European models deemed appropriate to "the spirit of the age" by Zaydān and others who formed part of a developing bourgeoisie that was, as this essay has argued, articulating itself into textual existence in the pages of these periodicals.

The first line of the Arabic translation of Verne's novel reads, "on the fifteenth day of the month of January in the year eighteen hundred and sixtytwo, the well-known English newspaper by the name of The Daily Telegraph ran the following short piece." 107 What follows is an announcement regarding the decision of one Samuel Ferguson to travel by hot air balloon, seeking to

\footnotetext{
104 Yāghī, 18; 20-1.

105 Roger Allen, "Sindbad the Sailor and the Early Arabic Novel," Tradition, Modernity, and Postmodernity in Arabic Literature: Essays in Honor of Professor Issa J. Boulatta, Kamal AbdelMalek and Wael Hallaq, eds. (Boston: Brill, 2000): 78-85.

106 Ian Watt, The Rise of the Novel (Berkeley: University of California Press, 2001), 32. Originally published 1957 .

${ }^{107}$ Jules Verne, Al-Riḥlah al-jawiyyah fì al-markabah al-hawäìyyah, Yūsuf Sarkīs, trans. (Beirut: Matba'at al-abā' al-mursalīn al-Yasūi iyyīn, 1883), 3.
} 
discover the "heart of Africa" and the "source of the Nile."108 The Daily Telegraph's editors announce too that they will be reporting on the events; their readers thought, at first, that this announcement must be some sort of "fairytale" (khuräfah). ${ }^{109}$ Verne's novel then tells us that a series of stories ran in the international European press mocking Ferguson, but before the end of the first chapter the order is placed in a Lyon factory for the manufacture of a piece of silk in the dimensions of the balloon.

Al-Zahrah, in what was to be one of its last issues, ran a story in late 1870 on hot air balloons, detailing the travels of two Frenchmen above the clouds darkening Parisian skies. ${ }^{110}$ While the journal had begun to publish current events in a serious tone, it may have been as difficult for readers of al-Zahrah as for those of The Daily Telegraph to decipher the veracity of this "strange occurrence." Al-Bashir also published a story on hot air balloons that same month, the third in a series on the uses of hot air balloons to the French forces during the Franco-Prussian War. ${ }^{11}$ The following year (1871), al-Bashir ran three more stories on hot air balloons. They outlined developments in the construction of balloons, detailed preparations one must make before travel (complete with a reference to the silk fabric needed), and also included a column on the dangers to which one might be exposed as a rider in hot air balloons. ${ }^{12}$ Two of al-Bashir's articles were reprinted the next week in the pages of al-Najāh. ${ }^{113}$ In al-Zahrah, al-Bashìr and al-Najāḥ's columns on hot air balloon travel as in the pages of the Arabic translation of Jules Verne's Cinq semaines en ballon, the fate of passengers hangs upon the strength of the balloon's construction. They are literally suspended in mid-air, held up only by a cleverly engineered piece of silk fabric, unsure of the future but placing their faith in the stunning advances of the time.

In the wake of the stories and articles on hot air balloons featured in al-Zahrah, al-Bashīr, and al-Najäh in 1870 and 1871, al-Nashrah al-Usbü iyyah ran a short, anecdotal piece on the final page of the last issue of 1871 entitled "miracle" (mu jizah). The story that followed told of a young French shepherd girl who was one day tending the flocks when a wooden chair fell from the sky and landed in a nearby bush. Seeing the chair, some thought it a gift from heaven. Others told them that they were mistaken in their theory of the chair's provenance, for no chair from heaven would be of such poor craftsmanship. A

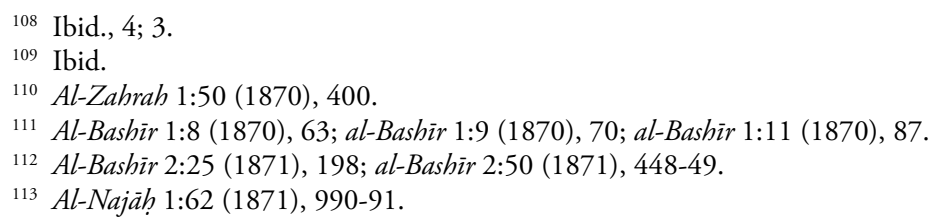


few days later, the local journals printed the fact that a hot air balloon had passed by overhead that cloudy day, and as it had been flying too low it needed to drop some extra weight. The production of consumer goods, advances in science, and an air of the fantastic are all here brought into play. Readers of Yūsuf Sarkīs's translation of Jules Verne's Cinq semaines en ballon alongside the many articles and stories on hot air balloon travel found in the journals of 1870s Beirut may well have identified with the reactions of the European newspaper readers in the opening pages of Verne's novel, unable to tell fact from fiction. However, unlike in the world of $A$ Thousand and One Nights, where readers are asked to suspend their disbelief in the magical powers of jinn, in the tales of hot air balloon travel, it is scientific advances that become imbued with a tinge of the fantastic.

The hot air balloon provides us with a foil through which to understand the role of $A$ Thousand and One Nights in the changing narrative modes of 1870 s and 1880s Beirut. The French missionary presence in the region which played a central role in the early history of the Arabic press in Beirut, as well as the wealth funding the new bourgeois lifestyles proliferating during this period, can be traced to the silk industry. ${ }^{114}$ Like the press, the exportation of raw silk was dominated by Christian families with ties to foreign consulates and missionaries, particularly after the events of 1860 that led to increased foreign and especially French intervention in the region. The best known silk factories in the region were run or financed by French companies, and the vast majority of silk produced in the region was for export to the south of France, where the silk would be refined. The Jesuits who published Sarkīs's translation of Cinq semaines en ballon, too, were from the south of France. Indeed, they were from Lyon, the site of the silk balloon manufacturers in the first chapter of Vernes's novel. The many hot air balloons filling the novels and journals published in Beirut during the 1870s and 1880s were the product, then, of exported raw silk from Beirut, finished in French factories in cities like Lyon. Silk is transformed from raw material to the stuff of modern tales verging on

114 For discussions on the role of the silk industry in transforming nineteenth-century Beirut, see: Leila Tarazi Fawaz, Merchants and Migrants in Nineteenth-Century Beirut (Cambridge, MA: Harvard University Press, 1983); Kamal Salibi, A House of Many Mansions: The History of Lebanon Reconsidered (Berkeley: University of California Press, 1988); Fawwaz Traboulsi, A History of Modern Lebanon (Ann Arbor, MI: Pluto Press, 2007); Akram Fouad Khater, Inventing Home: Emigration, Gender, and the Middle Class in Lebanon, 1870-1920 (Berkeley: University of California Press, 2001); Gaston Ducousso, L'industrie de la soie en Syrie et au Liban (Beirut, 1913); Boutros Labaki, Introduction à l'histoire économique du Liban: Soie et commerce extérieur en fin de période Ottomane, 1840-1914 (Beirut: Lebanese University Press, 1984); Maurice Chehab, Dawr Lubnān fì tārìkh al-ḥarī; and the aforecited volume History, Space and Social Conflict in Beirut: The Quarter of Zokak el-Blat, published by the Orient Institute of Beirut. 
the fantastic that are then imported as finished goods by the burgeoning presses of late nineteenth-century Beirut. The exposed narrative weave, with threads criss-crossing the Mediterranean, is not unlike the warp and weft of Arabic popular tales showing through in glimmers in the pages of the 1870 s and 1880s Arabic press. Now here, in an editor's efforts to retain his emergent bourgeois readership, now there, in that readership's fondness for suspense and the fantastic as it finds its place within the spirit of the age. 
Copyright of Journal of Arabic Literature is the property of Brill Academic Publishers and its content may not be copied or emailed to multiple sites or posted to a listserv without the copyright holder's express written permission. However, users may print, download, or email articles for individual use. 